\title{
REVIEW
}

\section{Hepatitis C and HIV-1 coinfection}

A H Mohsen, P Easterbrook, C B Taylor, S Norris

Gut 2002;51:601-608

Hepatitis $\mathrm{C}$ virus (HCV) has emerged as the cause of the second major epidemic of viral infection after human immunodeficiency virus (HIV) within the past two decades, and coinfection of HIV and HCV represents a growing problem for the future. This article reviews the current evidence on the epidemiology and clinical implications of an interaction between HIV-1 and HCV infection, and the current status of the management of patients with combined infection.

See end of article for authors' affiliations

Correspondence to

Dr A H Mohsen, Academic

Department of HIV/GU

Medicine, Weston

Education Centre, GKT

School of Medicine, King's

College, University of

London, London SE5 9RJ,

UK; Abdul.Mohsen@

kcl.ac.uk

Accepted for publication 4 December 2001
$\mathrm{H}$ epatitis $\mathrm{C}$ virus (HCV) has emerged as the cause of the second major epidemic of viral infection after human immunodeficiency virus (HIV) within the past two decades. Approximately $3 \%$ of the world's population are estimated to be infected, ${ }^{1}$ and viraemia persists in over $80 \% .^{2}$ Hepatitis $\mathrm{C}$ is now also recognised as one of the leading causes of chronic liver disease, and as a result mortality attributable to hepatitis $C$ is expected to more than triple over the next two decades and to exceed the number of HIV related deaths. ${ }^{3}$ Coinfection with HIV and HCV represents a growing problem for the future. In the USA, it has been estimated that there are 240000 coinfected subjects. ${ }^{4}$ Since the introduction of highly active retroviral therapy (HAART), and the dramatic improvement in the life expectancy of HIV infected subjects, the impact of HCV on mortality and development of hepatocellular carcinoma (HCC) has become more evident..$^{5-7}$ More recent studies in those coinfected with both HIV-1 and $\mathrm{HCV}$ have demonstrated that $\mathrm{HCV}$ is the leading non-acquired immunodeficiency syndrome (AIDS) cause of death in coinfected subjects, and end stage liver disease due to $\mathrm{HCV}$ infection accounts for up to $50 \%$ of all deaths. ${ }^{8}$ This article reviews the current evidence on the epidemiology and clinical implications of an interaction between HIV-l and HCV infection, and the current status of the management of patients with combined infection.

\section{METHODS}

We identified all relevant published articles or conference abstracts relating to the epidemiology, natural history, and treatment of HIV-1 and HCV coinfection over the past nine years. Medline and AIDSLINE databases were first searched using the terms "HIV" and "HCV", "liver disease", and for the treatment section we also used the terms "interferon", "antiretroviral therapy" in combination. Abstracts were included only where complete data were available. For prevalence studies we only included studies with $\geqslant 100$ patients. In the section on perinatal transmission, studies were included if they had at least 20 coinfected mothers and used either the presence of positive hepatitis C RNA at any time or HCV antibody detection at 12 months for the diagnosis of HCV infection in newborn babies. For the impact of HIV-l on HCV progression to fibrosis, cirrhosis, decompensated liver disease, or liver related deaths, we included all studies that investigated the effect of coinfection on any aspect of progression or mortality, including HCV viral load and transaminases. The same criteria were applied to studies examining the impact of HCV on HIV progression to AIDS or death, and on the impact of HCV treatment on HIV and HCV disease progression.

\section{PREVALENCE}

We identified 12 published seroprevalence studies based on various HIV-l infected cohorts from Europe $^{10-13}$ and North America, ${ }^{14-21}$ as shown in table 1 . HCV prevalence ranged between $7 \%$ and $57 \%$ and these differences in seroprevalence across the different studies were largely determined by the HCV risk factor distribution of the study population. Patients with a current or previous history of drug use had infection rates in excess of $80 \%^{12-14161720}$ while the prevalence of HCV in homo/bisexual groups varied between $2.6 \%$ and $15.2 \% .^{10121315-1720}$ The majority $(98 \%)$ of HIV-1 infected haemophiliacs are also coinfected with hepatitis C. ${ }^{62}$ However, even these data may underestimate the true prevalence of HCV among HIV positive patients as at least $4 \%$ of HIV-HCV coinfected patients have no detectable antibodies in the presence of HCV viraemia, ${ }^{24}{ }^{25}$ or as a result of immunosuppression may subsequently lose detectable antibodies from serum despite persistent viraemia. ${ }^{26}$

\section{"The majority (98\%) of HIV-1 infected haemophiliacs are also coinfected with hepatitis $C^{\prime \prime}$}

The consistently high prevalence of HCV infection observed in HIV-l infected individuals supports the routine screening for HCV in these patients, especially among haemophiliacs and drug users. Where HCV is suspected in the setting of negative antibody screening, detection of HCV RNA by polymerase chain reaction is recommended.

Abbreviations: $\mathrm{HCV}$, hepatitis $\mathrm{C}$ virus; HAART, highly active retroviral therapy; HCC, hepatocellular carcinoma; HIV-1, human immunodeficiency virus 1; AIDS, acquired immune deficiency syndrome; ALT, alanine aminotransferase; AST, aspartate aminotransferase. 
Table 1 Prevalence of hepatitis $\mathrm{C}$ virus $(\mathrm{HCV})$ in human immunodeficiency virus 1 infected patients

\begin{tabular}{|c|c|c|c|c|}
\hline Year, reference & Study size & Location & Characteristics of study population & $\%$ HCV positive \\
\hline \multicolumn{5}{|l|}{ Europe } \\
\hline $2000^{6}$ & $125^{*}$ & UK & Haemophiliacs & $98 \%$ \\
\hline $1998^{10}$ & 3048 & $\begin{array}{l}\text { Europe (central, northern } \\
\text { and southern) }\end{array}$ & $43 \%$ MSM, $27 \%$ IDU, $2.4 \%$ transfusion & $\begin{array}{l}33 \% \text { (MSM 6\%, IDU 91\%, } \\
\text { transfusion 59\%) }\end{array}$ \\
\hline $1999^{11}$ & 204 & Spain & $77 \%$ male, $26 \%$ MSM, $61 \%$ IDU & $57 \%$ \\
\hline $2000^{12}$ & 3111 & Switzerland & $65.6 \%$ male, $35.6 \%$ IDU, $33 \%$ MSM & $37.2 \%$ (IDU $87.7 \%$, MSM $3.7 \%$ ) \\
\hline $2000^{13}$ & 394 & Netherlands & $80 \%$ male, $58 \%$ MSM, $9 \%$ IDU & $15 \%$ (MSM 2.6\%, IDU 97\%) \\
\hline \multicolumn{5}{|l|}{ North America } \\
\hline $1991^{14}$ & 101 & Sacramento, USA & $\begin{array}{l}91 \% \text { male, } 30 \% \text { IDU, } 75 \% \text { sexual } \\
\text { promiscuity, } 7 \% \text { transfusion }\end{array}$ & $7 \%$ (IDU 16\%, transfusion $29 \%$ ) \\
\hline $1994^{15}$ & 512 & San Francisco, USA & $\begin{array}{l}98 \% \text { male, } 83 \% \text { MSM, } 7 \% \text { IDU, } 8.5 \% \\
\text { transfusion }\end{array}$ & $\begin{array}{l}14 \% \text { (MSM } 11.7 \% \text {, IDU } 40 \% \text {, } \\
\text { transfusion } 31.6 \% \text { ) }\end{array}$ \\
\hline $1998^{16}$ & 934 & New York, USA & $37 \%$ MSM, 37\% IDU, 4\% transfusion & $\begin{array}{l}40 \% \text { (MSM 12\%, IDU } 81 \% \text {, } \\
\text { transfusion } 78 \% \text { ) }\end{array}$ \\
\hline $1997^{17}$ & 587 & Hawaii, USA & $93.2 \%$ male, $75 \%$ MSM, $14 \%$ IDU & $17 \%$ (MSM 6.6\%, IDU 95\%) \\
\hline $1998^{18}$ & 511 & NIH, USA & All women & $32 \%$ \\
\hline $1999^{19}$ & 3134 & Texas, USA & Outpatients and prisoners & $43 \%$ \\
\hline $1999^{20}$ & 350 & Georgia, USA & $98.6 \%$ male, $47 \%$ MSM, $20 \%$ IDU & $33 \%$ (MSM 14\%, IDU 83\%) \\
\hline $1993^{21}$ & 226 & Toronto, Canada & $\begin{array}{l}94 \% \text { male, } 61 \% \text { of } \mathrm{HCV} \text { positive were } \\
\text { IDU, } 44 \% \text { were MSM, and transfusion } \\
22 \%\end{array}$ & $8 \%$ \\
\hline $1993^{22}$ & $382 *$ & USA & Haemophiliacs & $98 \%$ \\
\hline
\end{tabular}

MSM, men having sex with men, either homosexual or bisexual; IDU, previous or current intravenous drug use.

*Only two haemophiliac studies were included.

\section{TRANSMISSION}

HIV and HCV viruses share common routes of transmission, especially the parenteral route, and as a result coinfection rates in intravenous drug users and haemophiliacs are particularly high (60-90\%). ${ }^{622}{ }^{23}$ Other non-parenteral routes of transmission are also important, ${ }^{2728}$ and there is now increasing evidence that sexual ${ }^{15272930}$ and mother to child HCV transmission is facilitated by HIV infection. ${ }^{18}{ }^{31-35}$ In a study of 662 homosexual men, patients with HIV infection were three times more likely to be HCV positive compared with those who were HIV negative $(9 \% \vee 3 \% ; \mathrm{p}<0.001) .{ }^{30}$ In addition, independent sexual transmission of HCV among homosexual men accounted for approximately $50 \%$ of these cases. ${ }^{30}$

"There is now increasing evidence that sexual15272930 and mother to child HCV transmission is facilitated by HIV infection"

Similarly, there is a two to threefold higher maternal fetal transmission rate in coinfected mothers compared with a transmission rate of less than $6 \%$ in HIV negative mothers. ${ }^{18}{ }^{31-39}$

Table 2 summarises 10 studies of mother to child transmission in coinfected women comprising 1089 coinfected mothers. The vertical transmission rate ranged from a low of $5.8 \%$ in one study from the UK to $36 \%$ in a large study from Italy. Several factors were associated with a higher rate of HCV transmission in coinfected patients. These included a higher HCV viral load, ${ }^{18}{ }^{31}$ vaginal delivery, ${ }^{3435}$ and in one study breastfeeding increased HCV transmission by fourfold $(p=0.002)$ even after adjusting for mode of delivery. ${ }^{35}$ In contrast, caesarean section reduced the rate of HCV transmission, ${ }^{32} 34$ although this has not been corroborated in studies of HIV uninfected/HCV positive mothers, and cannot currently be recommended for management. ${ }^{35}$ Few studies have addressed the converse issue of the impact of HCV on HIV transmission in coinfected mothers. However, one study of 487 HIV infected mothers of whom 161 were also HCV infected found a 1.82-fold increased rate of mother to child HIV transmission (95\% confidence interval (CI) 1.12-2.95) in coinfected mothers. ${ }^{40}$

Table 2 Risk of hepatitis $\mathrm{C}$ virus ( $\mathrm{HCV}$ ) in mother to child transmission in HCV-human immunodeficiency virus (HCV-HIV) coinfected patients

\begin{tabular}{|c|c|c|c|c|c|}
\hline $\begin{array}{l}\text { Year, } \\
\text { reference }\end{array}$ & $\begin{array}{l}\text { No of coinfected } \\
\text { mothers/HCV } \\
\text { infected only }\end{array}$ & Location & $\begin{array}{l}\text { No HCV infected children (\%) } \\
\text { in coinfected/HCV infected } \\
\text { only (\%) }\end{array}$ & $\begin{array}{l}\text { Definition of HCV infection in } \\
\text { the child }\end{array}$ & $\begin{array}{l}\text { Factors associated with higher } \\
\text { transmission }\end{array}$ \\
\hline $1998^{18}$ & $41 / 112$ & USA & $7(17.1 \%) / 6(5.4 \%)$ & PCR positive at 6 months & $\begin{array}{l}\text { HIV }(p=0.04), H C V \text { viral load } \\
(p<0.001)\end{array}$ \\
\hline $1995^{31}$ & $22 / 94$ & Italy & $8(36 \%) / 0(0 \%)$ & PCR positive at 12 months & $\begin{array}{l}\text { HIV }(p<0.001), H C V \text { viral load } \\
(p=0.05)\end{array}$ \\
\hline $1997^{32}$ & $165 / 80$ & Italy & $25(15.1 \%) / 3(3.7 \%)$ & $\begin{array}{l}\text { PCR or HCV antibody positive at } \\
18 \text { months }\end{array}$ & HIV $(p=<0.01)$, VD $(p=0.06)$ \\
\hline $1998^{33}$ & $23 / 52$ & Italy & $4(17.4 \%) / 2(3.8 \%)$ & PCR positive at 6 months & HIV $(p=0.06)$ \\
\hline $2000^{34}$ & $22 / 328$ & UK, Ireland & $4(18.6 \%) / 21(6.4 \%)$ & PCR positive at 1 month & $\begin{array}{l}\text { HIV }(p=0.06) \text {, VD with emergency } \\
\text { CS v elective CS }(p=0.04)\end{array}$ \\
\hline $2001^{35}$ & $503 / 971$ & EU & $70(13.9 \%) / 60(6.6 \%)$ & $\begin{array}{l}\text { PCR or HCV antibody positive at } \\
18 \text { months }\end{array}$ & $\begin{array}{l}\text { OR }(95 \% \mathrm{CI}) \text { for } \mathrm{HCV} \text { transmission: } \\
\mathrm{HIV} \text {, OR } 3.76(\mathrm{Cl} 1.89-7.41)\end{array}$ \\
\hline $1993^{36}$ & $51 / 15$ & UK & $3(5.8 \%) / 1(6.6 \%)$ & PCR positive at 12 months & HIV (NS) \\
\hline $1995^{37}$ & $53 / 17$ & Italy & $12(23 \%) / 2(12 \%)$ & PCR positive at any time & HIV $(p=0.277)$ VD, $p<0.05$ \\
\hline $1995^{38}$ & $20 / 17$ & Italy & $4(20 \%) / 2(12 \%)$ & PCR positive at any time & HIV (NS) \\
\hline $1998^{39}$ & $73 / 49$ & USA & $5(7 \%) / 2(4 \%)$ & PCR positive at 18 months & HIV (NS) \\
\hline
\end{tabular}

CS, caesarean section; VD, vaginal delivery; $P C R$, polymerase chain reaction. 
Table 3 Impact of human immunodeficiency virus on hepatitis $\mathrm{C}$ virus (HCV) viral load in coinfected patients

\begin{tabular}{|c|c|c|c|c|c|}
\hline Year, reference & $\begin{array}{l}\text { No of coinfected } \\
\text { patients/HCV only } \\
\text { infected }\end{array}$ & Location & $\begin{array}{l}\text { Mean/ median } \\
\text { CD4 cell count }\end{array}$ & $\begin{array}{l}\text { Absolute increase in } \mathrm{HCV} \text { viral load in } \\
\text { coinfected related to HCV only infected }\end{array}$ & $\begin{array}{l}\text { Based on } \\
\text { evaluation at single } \\
\text { or multiple time } \\
\text { point }\end{array}$ \\
\hline $2001^{25}$ & $107 / 112$ & USA & 235 & $0.8 \log _{10}$ copies $/ \mathrm{ml}, \mathrm{p}=0.001$ & Single \\
\hline $1996^{41}$ & $42 / 37$ & USA & $>200$ & Only significant difference when CD4 $<200$ & Multiple \\
\hline $1993^{42}$ & $13 / 30$ & USA & $292-1024$ & $26.5 \times 10^{6}$ copies $/ \mathrm{ml}, \mathrm{p}<0.05$ & Single \\
\hline $1994^{43}$ & $17 / 17$ & USA & 201 & $25.6 \times 10^{5}$ eq genome $/ \mathrm{ml}, \mathrm{p}=0.006$ & Multiple \\
\hline $1995^{44}$ & $75 / 75$ & France & 278 & $101.7 \times 10^{5}$ eq genome $/ \mathrm{ml}, \mathrm{p}<0.0001$ & Single \\
\hline $1996^{45 a}$ & 27 (seroconverters) & USA & $>200$ & $0.59 \log _{10}$ copies $/ \mathrm{ml}, \mathrm{p}<0.0001$ & Multiple \\
\hline $1996^{45 b}$ & $80 / 20$ & USA & 200 & $0.33 \log _{10}$ copies, $p=0.021$ & Multiple \\
\hline $1999^{46}$ & $39 / 15$ & Italy & 206 & $0.53 \times 10^{6}$ copies $/ \mathrm{ml}, \mathrm{p}=0.01$ & Single \\
\hline $1998^{47}$ & $9 / 10$ & Netherlands & 739 & $1.08 \log _{10}$ copies/ml, p<0.0001 & Multiple \\
\hline $1999^{48}$ & $22 / 48$ & USA & 222 & $0.5 \log _{10}$ copies $/ \mathrm{ml}, \mathrm{p}=0.02$ & Single \\
\hline $2000^{49}$ & $39 / 69$ & Japan & 320 & $>2$-fold increase in mean, $p=0.02$ & Multiple \\
\hline $2001^{50}$ & $175 / 77$ & USA & 416 & $0.57 \log _{10}$ copies $/ \mathrm{ml}, \mathrm{p}<0.001$ & Multiple \\
\hline $2001^{51}$ & $107 / 112$ & USA & 235 & $0.91 \log _{10}$ copies $/ \mathrm{ml}, p<0.00001$ & Single \\
\hline $2000^{52}$ & $31 / 38$ & France & 652 & $0.5 \log _{10}$ copies $/ \mathrm{ml}, \mathrm{p}=0.016$ & Single \\
\hline $1995^{53}$ & $11 / 9$ & Spain & & 10 -fold higher, $p=0.07$ & Single \\
\hline $1996^{54}$ & $22 / 21$ & Germany & 325 & No effect & Single \\
\hline
\end{tabular}

Table 4 Impact of human immunodeficiency virus 1 on hepatitis $\mathrm{C}$ virus (HCV) progression

\begin{tabular}{|c|c|c|c|c|c|c|}
\hline $\begin{array}{l}\text { Year, } \\
\text { reference }\end{array}$ & $\begin{array}{l}\text { No of } \\
\text { coinfected/HCV } \\
\text { only infected } \\
\text { patients }\end{array}$ & Location & Mean follow up & Study outcome & OR/RR $(95 \% \mathrm{Cl})$ & Comment \\
\hline $1997^{5 *}$ & $1218 / 3647$ & UK & - & LRD & $3.21(1.89-5.44)$ unadjusted & Haemophiliacs \\
\hline $2000^{6}$ & $125 / 173$ & UK & $13.3 y$ & LRD & $\begin{array}{l}17.51(5.8-52.7) \text {, adjusted for age, } \\
\text { duration of HCV genotype }\end{array}$ & Haemophiliacs \\
\hline $1994^{15}$ & $74 / 438$ & USA & 28 months & Survival & $0.78(0.5-1.2)$, unadjusted & $\begin{array}{l}44 \% \text { had AIDS } \\
\text { (selected group) }\end{array}$ \\
\hline $1999^{20}$ & $115 / 235$ & USA & 141 months & Survival & $0.98(0.7-1.3)$ unadjusted & $\begin{array}{l}70 \% \text { had AIDS, } \\
\text { retrospective cohort }\end{array}$ \\
\hline $1999^{46}$ & $39 / 15$ & Italy & - & DLD & $12.8 \% \vee 0 \%$ & $\begin{array}{l}\text { All patients had severe } \\
\text { coagulopathy }\end{array}$ \\
\hline $1995^{53}$ & $32 / 44$ & Spain & - & Cirrhosis & $4.83(0.93-24.9)$ unadjusted & Histology based \\
\hline $1996^{56}$ & $36 / 102$ & UK & 18.8 y & Cirrhosis & $\begin{array}{l}3.9(1.4-10.8) \text {, adjusted for age, } \\
\text { haemophilia severity }\end{array}$ & Haemophiliacs \\
\hline $1998^{57}$ & $52 / 462$ & France & - & Cirrhosis & $\begin{array}{l}2.6(1.1-5.9) \text {, adjusted for age, } \\
\text { duration of } \mathrm{HCV} \text {, alcohol }\end{array}$ & $\begin{array}{l}\text { Cross sectional, } \\
\text { histology based }\end{array}$ \\
\hline $1999^{58}$ & $81 / 53$ & Canada & - & $\mathrm{PLD}^{\circ}$ & $7.4(2.2-25.5)$, age & Histology based \\
\hline $1999^{59}$ & $122 / 122$ & France & - & $\begin{array}{l}\text { Fibrosis } \\
\text { progression }\end{array}$ & $1.221(1.11-1.33)$, adjusted for $†$ & Histology based \\
\hline $1994^{60}$ & $103 / 152$ & UK & - & DLD & $21.4(2.6-174.5)$, duration of HIV & $\begin{array}{l}\text { FU } 15.1 \mathrm{y}, \\
\text { haemophiliacs }\end{array}$ \\
\hline $1993^{61}$ & $98 / 58$ & USA & $10 y$ & DLD & 3.2 (0.6-17), adjusted for age, ALT & Haemophiliacs \\
\hline $1997^{62}$ & $116 / 463$ & Spain & - & Cirrhosis & $1.94(0.92-4.1)$, duration of $\mathrm{HCV}$ & Histology based \\
\hline $1997^{63}$ & $22 / 33$ & Germany & - & Cirrhosis & $1(0.32-3.14)$ & Histology based \\
\hline $2001^{64}$ & $84 / 120$ & $\begin{array}{l}\text { Italy and } \\
\text { USA }\end{array}$ & - & $\begin{array}{l}\text { Fibrosis stage } 3 \\
\text { cirrhosis }\end{array}$ & $\begin{array}{l}3.2(1.1-9.2) \text {, adjusted for age, } \\
\text { alcohol, duration of HCV }\end{array}$ & $\begin{array}{l}\mathrm{CD} 4<500 \text {, histology } \\
\text { based }\end{array}$ \\
\hline $1997^{65}$ & $48 / 11$ & Spain & - & Fibrosis & $\begin{array}{l}17.9(2.5-129) \text {, adjusted for } \\
\text { genotype, duration of HCV }\end{array}$ & Histology based \\
\hline $1996^{66}$ & $144 / 72$ & Germany & 63.9 months & LRD & $7 \% \vee 0 \%$ & - \\
\hline
\end{tabular}

*Patients with HIV were considered coinfected with hepatitis $C$ if they were exposed to high risk blood products.

†Severe immunosuppression (CD4 $<200$ cells), sex, alcohol, age at HCV infection.

PLD, progressive liver disease; LRD, liver related death; FU, follow up; OR, odds ratio; RR, relative risk; $95 \% \mathrm{Cl}, 95 \%$ confidence interval.

The majority of studies have reported higher HCV viral loads by a magnitude of $0.3-1.08 \log$ RNA copies $/ \mathrm{ml}$ in coinfected patients ${ }^{25}{ }^{41-53}$ compared with HIV-1 negative HCV infected subjects (table 3), and this is likely to mediate the higher transmission of HCV in the setting of HIV infection. However, one report suggests that this may be the case only in patients infected with HCV genotype $1 .^{54}$ An association between serum HCV viral load and saliva HCV viral load has also been recently demonstrated, which may have major implications for HCV transmission in coinfected patients. ${ }^{55}$

Together, these data demonstrate a higher rate of vertical and sexual transmission of HCV in coinfected patients, and that HIV is a cofactor for HCV transmission.

\section{IMPACT OF HIV ON HCV PROGRESSION}

Prior to HAART, the majority of deaths in HIV infected patients were AIDS related, and data on HCV related morbidity and mortality were lacking. ${ }^{15}$ However, since HAART became widely available in the last five years and extended life expectancy, the management of concurrent illnesses has attracted more attention. Table 4 summarises data from 17 studies $^{56152046535666}$ on the impact of HIV infection on HCV progression, comprising a total of 2509 coinfected patients. A recent meta-analysis included eight of these studies ${ }^{56-63}$ and showed a combined adjusted relative risk of 2.92 (95\% CI 1.70-5.0) for progression to cirrhosis or decompensated liver disease in coinfected patients. ${ }^{67}$ Similar evidence for liver related deaths was provided by the UK haemophiliac cohort of 
Table 5 Impact of hepatitis C virus (HCV) infection on human immunodeficiency virus (HIV) progression

\begin{tabular}{|c|c|c|c|c|c|c|}
\hline $\begin{array}{l}\text { Year, } \\
\text { reference }\end{array}$ & Location & $\begin{array}{l}\text { No of } \\
\text { coinfected } \\
\text { patients/HIV } \\
\text { infected alone }\end{array}$ & $\begin{array}{l}\text { Duration of follow } \\
\text { up }\end{array}$ & Outcome & OR/RR (95\% Cl) & Comment \\
\hline $2001^{7}$ & Canada & $78 / 104$ & 42 months & Death & $1.59(1.06-6.32)$ unadjusted & $1-$ \\
\hline $1994^{15}$ & USA & $74 / 438$ & 84 months & Death & $0.85(0.30-2.4)$ unadjusted & Selected group \\
\hline $1999^{20}$ & USA & $122 / 228$ & 141 months & AIDS and death & No effect & $70 \%$ had AIDS \\
\hline $2000^{12}$ & Switzerland & $528 / 1068$ & 28 months & $\begin{array}{l}\text { AIDS and death } \\
\text { Clinical progression }\end{array}$ & $\begin{array}{l}3.45(2.0-6.25) \\
1.72(1.25-2.36)\end{array}$ & $\begin{array}{l}\text { Patients with well controlled } \\
\text { HIV-1 replication }\end{array}$ \\
\hline $1993^{21}$ & USA & $18 / 195$ & - & AIDS & $0.3(0.084-1.07)$ & - \\
\hline $1999^{58}$ & Canada & $22 / 59$ & 17.2 y & AIDS and death & $2(1.06-3.9)$ & $\begin{array}{l}\text { Patients with progressive liver } \\
\text { disease }\end{array}$ \\
\hline $2001^{75}$ & USA & 207 & $7 y$ & $\begin{array}{l}\text { AIDS } \\
\text { Death }\end{array}$ & $\begin{array}{l}1.66(1.1-2.51)) \\
1.54(1.03-2.30)\end{array}$ & Haemophiliacs \\
\hline $1998^{76}$ & France & $119 / 119$ & $3 y$ & AIDS and death & $\begin{array}{l}1.64(1.06-2.06) \text { adjusted } \\
\text { for CD4 cell count }\end{array}$ & - \\
\hline $1995^{77}$ & Italy & $214 / 202$ & 30 months & AIDS & $\begin{array}{l}0.97(0.52-1.79) \text { adjusted } \\
\text { for CD4 cell count }\end{array}$ & $\begin{array}{l}\text { AIDS free cohort with known } \\
\text { seroconversion date }\end{array}$ \\
\hline
\end{tabular}

305 patients of whom 125 were coinfected. The relative hazard of liver related death, adjusted for age and HCV genotype, was 17.5-fold for coinfected patients (95\% CI 5.8-52.7) compared with those infected with HCV alone. ${ }^{6}$ More recently, the UK National Haemophilia Register has reported that men with haemophilia exposed to HCV and HIV are 4.6-fold more likely to progress to liver related death (6.5\%; range 4.5-9.5\%) compared with HIV-1 uninfected men (1.4\%; range $4.5-9.5 \%){ }^{5}$

\section{"Men with haemophilia exposed to HCV and HIV are 4.6-fold more likely to progress to liver related death compared with HIV-1 uninfected men"}

Identification of factors influencing $\mathrm{HCV}$ disease progression in HIV coinfected patients has been based mainly on haemophiliac cohorts and has not been assessed adequately in other HIV risk groups. Level of CD4 immunosuppression has emerged as one of the most important determinants of progression to liver fibrosis, and patients with CD4 cell counts less than 500 cells $\times 10^{9} / 1$ are 3.2 times (95\% CI 1.1-9.2) more likely to have advanced liver fibrosis on liver biopsy. ${ }^{64}$ Patients with a low CD4 count or who had an AIDS diagnosis were also at increased risk for severe liver disease ${ }^{59-61}{ }^{64}$ Other host factors associated with more rapid HCV disease progression include older age at infection and excess alcohol intake. ${ }^{59}$ As for HCV transmission, the impact of HIV on HCV progression is likely to be partly mediated through the increased HCV viral load (table 3). A higher HCV viral load was shown in three studies to correlate with increased hepatic inflammation, as defined by a higher alanine aminotransferase (ALT) value ${ }^{43}{ }^{49}{ }^{50}$ but this has not been confirmed in other studies. ${ }^{25} 41424546485154$ In addition, an association between HCV viral load and fibrosis progression has not been clearly demonstrated even in HIV-1 uninfected HCV patients, and a positive correlation with histological grade and stage of disease is lacking. ${ }^{68}$ There are conflicting data on the impact of HCV genotype on disease progression in coinfected patients. Two studies have shown no effect of genotype on progression ${ }^{57}{ }^{64}$ while a further two have shown the presence of genotype 1 to be associated with more advanced fibrosis stage $e^{65}$ and liver related death. ${ }^{6}$ Other potential risk factors such as mode of acquisition, past hepatitis B infection, and HCV viral load have not been assessed in coinfected populations.

HCV is a known carcinogen, ${ }^{69}$ and the rising prevalence of infection has been implicated as a major contributing factor to the recent increase in incidence of hepatocellular carcinoma (HCC) in the USA. ${ }^{70}$ The precise mechanism by which HCV induces carcinogenesis is unclear, but animal studies in transgenic mice have implicated the core protein, ${ }^{71}$ which has been reported to downregulate p53 promoter activity ${ }^{72}$ and repress p2 1 promoter activity through the p53 pathway. ${ }^{73}$ These events may form the basis for the direct role of HCV in the induction of HCC. It has recently been reported that HCC occurs at a younger age in coinfected patients compared with those infected with HCV alone. ${ }^{74}$ While further follow up data are needed, this trend is expected to continue over the coming years as the impact of HCV related liver injury in HIV infected subjects gains further attention.

\section{"HCC occurs at a younger age in coinfected patients compared with those infected with HCV alone"}

The consensus from these studies is that HIV-1 is clearly associated with accelerated liver disease and reduced survival in HCV infected patients. In altering the rate of fibrosis progression, HIV-1 may further alter the natural history of HCV infection resulting in an aggressive course to end stage liver disease and liver failure.

\section{IMPACT OF HCV ON HIV-1 PROGRESSION}

The impact of HCV infection on the course of HIV disease has become evident in recent years, and the findings of nine studies are summarised in table 5, ${ }^{72} 1520215875-77$ four of which were conducted before the widespread availability of triple combination of antiretroviral therapy. In five studies HCV infection appears to have a significant effect on the progression of HIV to AIDS defining illness and AIDS related mortality. ${ }^{1258} 7576 \mathrm{In}$ the largest study reported to date, based on a Swiss HIV cohort of patients with well controlled HIV-1 replication, 1593 of whom were coinfected, the risk of progression to AIDS defining illness or death was 3.54 (95\% CI 2.0-6.25) compared with HCV uninfected individuals. Daar et al have also reported a detrimental effect of HCV viral load on HIV progression. For every 10 -fold increase in baseline HCV viral load, the relative risk for clinical progression to AIDS was 1.66 (95\% CI 1.1-2.51), and the relative risk for AIDS related mortality was 1.54 (95\% CI 1-2.3), even after controlling for $\mathrm{CD}^{+}$cell count and HIV-1 RNA level. ${ }^{75}$ The evidence from these studies confirms that HCV is an independent factor associated with HIV progression to AIDS and AIDS related death. However, four studies failed to demonstrate a negative effect of HCV on HIV progression. ${ }^{15} 202177$ In one study, 70\% of patients already had AIDS ${ }^{20}$; two studies were based on retrospective ${ }^{15}$ or cross sectional analyses, ${ }^{21}$ and in a further study the follow up was 30 months. ${ }^{77}$ Reasons for the adverse effect of HCV on HIV disease are unknown. One possible explanation is that patients with coinfection, the majority of whom have acquired their infection through injection drug use, may have reduced compliance with HIV therapies. 
Table 6 Relationship between hepatitis $C$ virus (HCV) viral load (VL) and CD4 count in coinfected patients

\begin{tabular}{|c|c|c|c|c|}
\hline $\begin{array}{l}\text { Year, } \\
\text { reference }\end{array}$ & Country & $\begin{array}{l}\text { No of patients } \\
\text { coinfected }\end{array}$ & $\begin{array}{l}\text { Mean CD4 cell } \\
\text { count/median }\end{array}$ & Results \\
\hline $1996^{41}$ & USA & 42 & $>200$ & $r=0.34, p=0.04$ \\
\hline $1994^{43}$ & USA & 17 & 201 & $r=-0.56, p=0.006$ \\
\hline $1996^{45}$ & USA & 27 & $>200$ & $\begin{array}{l}0.36 \text { log HCV-VL increase for } \\
\text { every log increase in CD4 }\end{array}$ \\
\hline $1999^{46}$ & Italy & 39 & 206 & $r=-0.23, p=0.08$ \\
\hline $1998^{47}$ & Netherlands & 9 & 696 & $r=-0.22, p<0.05$ \\
\hline $2000^{49}$ & Japan & 39 & 320 & $r=-0.34, p=0.07$ \\
\hline $2001^{50}$ & USA & 175 & 416 & $\begin{array}{l}\text { For every } 100 \text { cell increase } \\
\text { HCV-VL decreased by } 0.19 \\
\log _{10}, p=0.002\end{array}$ \\
\hline $1997^{62}$ & Spain & 116 & CD4 $<500$ cells & $r=-0.323, p=0.07$ \\
\hline $2001^{25}$ & USA & 112 & 235 & No relation \\
\hline $1993^{42}$ & USA & 13 & $292-1024$ & No relation \\
\hline $1995^{44}$ & France & 75 & 278 & No relation \\
\hline $1999^{48}$ & USA & 22 & 222 & No relation \\
\hline $1996^{54}$ & Germany & 22 & 325 & No relation \\
\hline
\end{tabular}

"HCV is an independent factor associated with HIV progression to AIDS and AIDS related death"

Thirteen studies have examined the impact of HCV viral load on CD4 cell counts (table 6); eight of these have highlighted an inverse correlation between HCV viral load and CD4 count ${ }^{41} 434647495062$ while five studies have shown no relationship, 254244854 and one study reported a positive correlation. $^{45}$ It has been suggested that this inverse relationship between HCV viral load and CD4 count may be explained on the basis of immune dysregulation of HCV replication. ${ }^{49} 75$

\section{PATHOGENESIS OF HIV-1-HCV INTERACTION}

Several lines of evidence suggest that liver injury in HCV patients is due to the immune response to HCV rather than a direct viral effect. Strong HCV specific T helper 1 cell responses and $\mathrm{T}$ helper cell recognition of multiple core epitopes are associated with clearance of HCV naturally and after interferon therapy. ${ }^{78-80}$ Furthermore, HCV specific CD4+ and CD8 $+\mathrm{T}$ cells have been shown to persist as biomarkers for prior HCV exposure and recovery, even if HCV antibodies decline and become undetectable. ${ }^{81}$ HIV-1 infects CD4 cells which leads to impaired response of both the infected CD4+ T cells and the uninfected CD8 + T cells, and this functional loss eventually leads to profound immune dysregulation. ${ }^{82}$ The impaired immune response to $\mathrm{HCV}$ in the setting of HIV infection may explain the inability of coinfected patients to clear HCV infection naturally, and possibly also the poor response to current treatment.

\section{"The mechanism by which HCV influences HIV-1 progression remains speculative"}

The mechanism by which HCV influences HIV-l progression remains speculative. HCV may downregulate proliferation of $\mathrm{T}$ cells ${ }^{83}$ or increase apoptosis of $\mathrm{T}$ cells by apoptotic pathways. ${ }^{84}$ Patients with HCV infection express Fas on peripheral blood mononuclear cells and HCV-RNA has preferentially been detected in these Fas positive cells. ${ }^{85}$ This may form the basis for a synergistic effect of HIV-l and HCV on CD4 positive cells both in terms of production and apoptosis which in turn could explain the negative impact of HCV on HIV progression.

\section{IMPACT OF HIGHLY ACTIVE ANTIRETROVIRAL HIV THERAPY ON HCV PROGRESSION}

A total of eight studies examined the impact of HAART on HCV progression. Five studies found no evidence for an effect of HAART on HCV replication ${ }^{86-90}$ while two studies have reported significant transient increases in HCV viral load ${ }^{91}$ and transaminases (ALT, aspartate aminotransferase (AST)) following introduction of HAART. A protective effect of HAART on fibrosis progression has also been suggested ${ }^{59}$ but needs to be confirmed in large prospective studies. One report has also shown a significant increase in HCV viral load at 96 weeks post HAART compared with baseline, although samples taken at 24 weeks post HAART did not show a significant increase. ${ }^{33}$ The mechanism for the higher HCV-RNA levels with HAART despite immune restoration is unclear but is probably not associated with HIV related immune dysfunction. However, the increase in transaminases is associated with an improving immune response as shown by a correlation with a reduction in HIV viral load and increase in CD4 cell count. ${ }^{90-9294}$ In one study, multivariate logistic regression analysis demonstrated that a HAART induced CD4 cell count increase of 50 cells or more was independently associated with severe hepatotoxicity (odds ratio 3.6; 95\% CI 1.0-12.9) in coinfected patients. ${ }^{94}$

A number of studies have also identified HCV as a strong predictor of the development of hepatotoxicity (elevation of AST and ALT of over 1.25 times from baseline) with HAART, ${ }^{13497}$ in addition to other factors such as ritonavir use $^{9497}$ and hyperbilirubinaemia associated with indinavir treatment. Of 138 HIV patients treated with indinavir, hyperbilirubinaemia occurred in 56 (40.6\%), and HCV was an independent predictor of hepatotoxicity. ${ }^{98}$ Hepatotoxicity has also been observed with the use of reverse transcriptase inhibitors which can cause mitochondrial toxicity and microsteatosis, and which may also lead to lethal hepatotoxicity. ${ }^{99}$ More recently, HCV was shown to be a confounding factor for the development of lipoatrophy in coinfected patients $(p=0.003)$, and in a multivariate analysis HCV was independently associated with insulin resistance, body mass index, and peripheral fat wasting. ${ }^{100}$

In conclusion, there is no definitive evidence to support a clear effect of HAART on the natural history of HCV infection but HCV infection appears to be an independent predictor of hepatotoxicity following the introduction of HAART. The relationship of liver toxicity to antiretroviral therapy depends on the specific antiretroviral agent and the degree of immune reconstitution. 


\section{IMPACT OF HCV TREATMENT ON HIV DISEASE PROGRESSION}

Treatment of HCV infection has evolved over the last decade with an increasingly higher percentage of patients achieving sustained viral clearance (defined as HCV RNA negative at six months after stopping therapy) following the introduction of combination based therapies with interferon and ribavirin, and more recently pegylated interferon. ${ }^{101-104}$ Of note, HCV-HIV coinfected patients were all excluded from placebo controlled trials with interferon alpha. However, the results of nine nonplacebo controlled trials ${ }^{62105-111}$ showed an equivalent percentage who had a sustained response to HCV therapy in coinfected compared with HCV only infected individuals. This ranged between $8 \%$ and $29 \%$, although the interferon dosage and duration varied considerably across the different studies (from 3 to 9 million units weekly for 6-12 months). Side effects of interferon in coinfected patients were comparable with HIV uninfected patients..$^{52}$ Over $90 \%$ of patients were able to complete their treatment course indicating that interferon is well tolerated even when used in conjunction with antiretroviral therapy. A 5\% drop in CD4 cell count occurred in less than $5 \%$ of patients treated, and occurred in the first 10 weeks of therapy. However, this decline in CD4 count may be clinically significant and contribute to the subsequent development of opportunistic infections. ${ }^{52112113}$

Combination therapy with interferon alpha and ribavirin is the current gold standard in the treatment of HCV infection. ${ }^{103}{ }^{104}$ Based on three studies, 80 coinfected patients treated with interferon and ribavirin showed a comparable sustained viral response rate and incidence of side effects to HIV uninfected patients, ${ }^{114-116}$ and the results of several large studies are awaited. Five cases of mitochondrial toxicity have been reported in coinfected patients receiving interferon and ribavirin and were thought to relate to the interaction of ribavirin with didanosine $e^{117118}$ as a result of enhanced phosphorylation of didanosine which reached toxic levels. ${ }^{119}$ In all studies published thus far, the HIV viral load did not change when ribavirin was commenced in patients who were already receiving antiretroviral therapy.

"The development of a helicase inhibitor, which is anticipated in the near future, together with other novel approaches, are antisense genes, ribozymes, and $\mathrm{HCV}$ specific protease inhibitors"

The recent introduction of pegylated interferon in combination with ribavirin appears to further improve the rate of sustained viral response and patient compliance. Preliminary data report that the regimen is well tolerated with $65 \%$ achieving viral clearance at six months. ${ }^{120}$ The development of a helicase inhibitor which is anticipated in the near future, together with other novel approaches, are antisense genes, ribozymes, and HCV specific protease inhibitors. Immunotherapy may also have a place in the future. Schlaak et al showed HCV viral clearance in two $(28.6 \%)$ of seven coinfected patients treated with interleukin 2. ${ }^{121}$ Future HCV therapy is therefore likely to include multiple combinations similar to those used in HIV therapy.

\section{TRANSPLANTATION}

In the past, the presence of HIV infection was generally considered a contraindication for liver transplantation. This was partly related to the ethical debate over allocation of limited health care resources and the difficulty in justifying the use of live related donors when life expectancy was limited for other reasons. However, following the introduction of HAART and subsequent prolonged survival of HIV patients, organ transplantation as a treatment strategy for HCV infection is being evaluated in a number of centres. At King's College Hospital, 1000 liver recipient transplants were performed between
1995 and 2001, of which 10 patients were HIV infected ${ }^{122}$ and five had HIV-1-HCV coinfection. Three presented with fulminant liver failure, in two due to hepatitis B infection, in one due to non-A non-B infection (although he was also infected with hepatitis B), and in one due to end stage alcoholic liver disease. All survived the postoperative period and were discharged home. Four patients died subsequently at $3,6,15$, and 25 months following transplantation, and the cause of death in these patients was hepatitis $\mathrm{C}$ complications as a result of reinfection.

\section{"Organ transplantation as a treatment strategy for $\mathrm{HCV}$ infection is being evaluated in a number of centres"}

None of the patients with hepatitis B developed graft reinfection post transplant, and six patients are currently alive with the longest survival now over 42 months. Only one patient developed complications related to HIV infection. The treatment related immunosuppressive drugs were well tolerated and infective complications and HIV progression were uncommon. Thus liver transplantation may be an option in carefully selected patients.

\section{INTERACTION OF HCV-HIV-1 COINFECTION AND HEPATITIS A AND HEPATITIS B}

There are no available data on vaccination in coinfected patients and therefore vaccination of HCV-HIV infected patients remains controversial. Acute hepatitis A has been shown to be more severe and associated with higher mortality in patients infected with HCV and especially in those with advanced liver disease. ${ }^{123}$ However, other groups have not confirmed this finding. ${ }^{124}$ The response of hepatitis A vaccination in HIV positive patients is high, with up to $88 \%$ mounting an antibody response and without adverse effect. ${ }^{125}$

\section{"Vaccination of HCV-HIV infected patients remains controversial"}

Selective hepatitis A vaccination may be indicated in HIV-HCV coinfected patients who have not been exposed previously. Past hepatitis B exposure as defined by hepatitis B core antibody positive in HIV uninfected patients has also been shown to be a strong predictor of severe liver disease. ${ }^{2}$ This observation was confirmed by paired liver biopsies where past hepatitis B infection was an independent marker of progression. Furthermore, hepatitis B is associated with more advanced liver disease in patients with chronic hepatitis C. ${ }^{126}$ Patients with HIV-HCV coinfection who have not been exposed to hepatitis $\mathrm{B}$ should therefore be vaccinated. Currently, combined hepatitis A and B vaccination is available and will facilitate more convenient delivery of protective vaccination.

\section{Authors' affiliations}

A H Mohsen, P Easterbrook, Academic Department of HIV/GU

Medicine, King's College, University of London, London, UK

C B Taylor, Department of Sexual Health, King's College, University of London, London, UK

S Norris, Department of Hepatology, King's College, University of

London, London, UK

\section{REFERENCES}

1 WHO. Hepatitis C: Global Update. Wkly Epidemiol Rec 1997:72:341-4.

2 Mohsen AH, Trent HCV Study Group. The epidemiology of hepatitis C in a UK health regional population of 5.12 million. Gut 2001;5:707-13. 3 National Institutes of Health Consensus Development Conference Panel Statement: management of hepatitis C. Hepatology 1997;26:2-10S.

4 Sulkowski MS, Mast EE, Seeff LB, et al. Hepatitis C virus infection as an opportunistic disease in persons infected with human immunodeficiency virus. Clin Infect Dis 2000;30(suppl 1):S77-84. 
5 Darby SC, Ewart DW, Giangrande PL, et al. Mortality from liver cancer and liver disease in haemophilic men and boys in UK given blood products contaminated with hepatitis C. UK Haemophilia Centre Directors' Organisation. Lancet 1997; 15:350:1425-31

6 Yee TT, Griffioen A, Sabin CA, et al. The natural history of HCV in a cohort of haemophilic patients infected between 1961 and 1985. Gut 2000;47:845-51.

7 Klein MB, Lalonde RG, Suissa S. Hepatitis C coinfection is associated with increased morbidity and mortality among HIV-infected patients. 8th Conference on Retroviruses and Opportunistic Infections 2001, abstract 569

8 Bica I, McGovern BH, Dhar R, et al. Increasing mortality due to end-stage liver disease in patients with human immunodeficiency virus infection. Clin Infect Dis 2001;32:492-7.

9 Soriano V, Garcia-Samaniego J, Valencia E, et al. Impact of chronic liver disease due to hepatitis viruses as cause of hospital admission and death in HIV-infected drug users. Eur J Epidemiol 1999;15:1-4.

10 Binfield T, Cent C. Hepatitis C in the EuroSIDA cohort of European HIV-infected patients: prevalence and prognostic value. 12th World AIDS Conference, Geneva, Switzerland, Geneva, Switzerland, 1998: abstract 22261.

11 Negredo E, Domingo $P$, Sambeat $M$, et al. Influence of coinfection with hepatitis virus on human immunodeficiency plasma viral load. Arch Med 1999;59:2367-8.

12 Greub G, Ledergerber B, Battegay $M$, et al. Clinical progression, survival, and immune recovery during antiretroviral therapy in patients with HIV-1 and hepatitis $\mathrm{C}$ virus coinfection: the Swiss HIV Cohort Study. Lancet 2000;356:1800-5.

13 Brinker MD, Wit FWNM, Dillen PMEW, et al. Hepatitis B and C virus co-infection and the risk for hepatotoxicity of highly active antiretroviral therapy in HIV-1 infection. AIDS 2000;14:2895-902.

14 Hayashi PH, Flynn N, McCurdy SA, et al. Prevalence of hepatitis C virus antibodies among patients infected with human immunodeficiency virus. J Med Virol 1991;33:177-80.

15 Wright TL, Hollander $\mathrm{H}, \mathrm{Pu}$ X, et al. Hepatitis $\mathrm{C}$ in HIV-infected patients with and without AIDS: prevelance and relationship to patients survival. Hepatology 1994;20: 1152-5

16 Merrick ST, Sepkowitz KA, Boyle BA, et al. Seroprevalence of hepatitis $C$ antibody and hepatitis B surface antigenemia in a large urban HIV clinic. 12th World AIDS Conference, Geneva, Switzerland, 1998: abstract 22263.

17 Vogt RL, Richmond-Crum S, Diwan A. Hepatitis C infection in human immune deficiency virus-positive cohort in Hawaii. J Infect Dis 1997; 176:542-3

18 Thomas DL, Villano SA, Riester KA, et al. Perinatal transmission of hepatitis $C$ virus from human immunodeficiency virus type 1 -infected mothers. Women and Infants Transmission Study. J Infect Dis 1998; 177:1480-8.

19 Pollard RB. Analogy of human immunodeficiency virus to hepatitis $C$ virus: the human immunodeficiency model. Am J Med 1999;107(suppl):41-4

20 Staples CT Jr, Rimland D, Dudas D. Hepatitis C in the HIV Atlanta V.A (Veterans Affairs Medical Center) Cohort Study (HAVACS): the effect of coinfection on survival. Clin Infect Dis 1999:29:150-4.

21 Quan CM, Krajden M, Grigoriew GA, et al. Hepatitis C virus infection in patients infected with human immune deficiency virus. Clin Infect Dis 1993; 17:117-9

22 Troisi CL, Hollinger FB, Hoots WK, et al. A multicenter study of viral hepatitis in a United States hemophilic population. Blood 1993; 81:412-18.

23 Centers for Disease Control and Prevention. Recommendations for prevention and control of hepatitis $C$ virus (HCV) infection and HCV-related chronic disease. MMWR Morb Mortal Wkly Rep 1998:47(RR-19): 1 .

24 Bonacini $\mathbf{M}$, Lin HJ, Hollinger FB. Prevalence of HCV RNA in HIV-infected patients. J Hepatol 1999;30(suppl 1):135

25 Bonacini M, Lin HJ, Hollinger FB. Effect of coexisting HIV-1 infection on the diagnosis and evaluation of hepatitis $C$ virus. J Acquir Immune Defic Syndr 2001;26:340-4

26 Chamot E, Hirchel B, Wintsch J, et al. Loss of antibodies against hepatitis $\mathrm{C}$ virus in HIV-seropositive intravenous drug users. AIDS 1990;4:1275-7

27 Soto B, Rodrigo L, Garcia-Bengoechea M, et al. Heterosexual transmission of hepatitis $C$ virus and the possible role of coexistent human immunodeficiency virus infection in the index case. A multicentre study of 423 pairings. J Intern Med 1994;236:515-19.

28 Green ST, Mohsen AH, McKendrick MW, et al. Potential for hepatitis C transmission among non-needle/syringe sharing Sheffield drug injectors through the sharing of drug preparation paraphernalia. Commun Dis Public Health 2001:4:38-41.

29 Thomas DL, Zenilman JM, Alter HJ, et al. Sexual transmission of hepatitis $C$ virus among patients attending sexually transmitted diseases clinics in Baltimore-an analysis of 309 sex partnerships. J Infect Dis 1995; 171:768-75

30 Craib KJP, Sherlock CH, Hogg RS, et al. Evidence of sexual transmission of hepatitis $\mathrm{C}$ virus (HCV) in a cohort of homosexual men. 8th Conference on Retroviruses and Opportunistic Infections, Chicago, 2001: abstract 561

31 Zanetti AR, Tanzi E, Paccagnini S, et al. Mother-to-infant transmission of hepatitis $C$ virus. Lancet 1995;345:289-91.

32 Tovo PA, Palomba E, Ferraris G, et al. Increased risk of maternal-infant hepatitis $C$ virus transmission for women coinfected with human immunodeficiency virus type 1. Clin Infect Dis 1997;25:1121-4.
33 Mazza C, Ravaggi A, Rodella A, et al. Prospective study of mother-to-infant transmission of hepatitis $\mathrm{C}$ virus (HCV) infection. J Med Virol 1998;54:12-19

34 Gibb DM, Goodall RL, Dunn DT, et al. Mother-to-child transmission of hepatitis $C$ virus: evidence for preventable peripartum transmission. Lancet 2000;356:904-7.

35 European Paediatric Hepatitis C Virus Network. Effects of mode of delivery and infant feeding on the risk of mother-to-child transmission of hepatitis C virus. Br J Obstet Gynaecol 2001;108:371-7

36 Lam JPH, McOmish F, Burns SM, et al. Infrequent vertical transmission of hepatitis $C$ virus. J Infect Dis 1993;167:572-6.

37 Paccagnini S, Principi N, Massironi E, et al. Perinatal transmission and manifestation of hepatitis $C$ virus infection in a high risk population. Pediatr Infect Dis J 1995;14:195-9.

38 Zuccotti GV, Ribero ML, Giovannini M, et al. Effect of hepatitis C genotype on mother-to-infant transmission of virus. J Pediatr 1995; 127:278-80.

39 Granovsky MO, Minkof HL, Tess BH, et al. Hepatitis $\mathrm{C}$ virus infection in the mothers and infants cohort study. Pediatrics 1998;102:355-9.

40 Hershow RC, Riester KA, Lew J, et al. Increased vertical transmission of human immunodeficiency virus from hepatitis $C$ viruscoinfected mothers. J Infect Dis 1997:176:414-20.

41 Ghany MG, Leissinger C, Lagier R, et al. Effect of human immunodeficiency virus infection on hepatitis $C$ virus infection in haemophiliacs. Dig Dis Sci 1996;41:1265-72.

42 Sherman KE, O'Brien J, Gutierrez AG, et al. Quantitative evaluation of hepatitis $C$ virus RNA in patients with concurrent human immunodeficiency virus infection. J Clin Microbiol 1993;31:2679-82.

43 Eyster ME, Fried MW, Di Bisceglie AM, et al. Increasing hepatitis C virus RNA levels in hemophiliacs: relationship to HIV infection and live disease. Blood 1994;84:1020-3.

44 Cribier B, Rey D, Schmitt C, et al. High hepatitis C viremia and impaired antibody response in patients coinfected with HIV. AIDS 1995;9:1131-6.

45 Thomas DL, Shih JW, Alter HJ, et al. Effect of human immunodeficiency virus on hepatitis $C$ virus infection among injecting drug users. J Infect Dis 1996; 174:690-5.

46 Dragoni F, Cafolla A, Gentile G, et al. HIV-HCV RNA loads and liver failure in coinfected patients with coagulopathy. Haematologica 1999;84:525-9

47 Beld $M$, Penning $M$, Lukashov V, et al. Evidence that both HIV and $\mathrm{HIV}$-induced immunodeficiency enhance $\mathrm{HCV}$ replication among $\mathrm{HCV}$ seroconverters. Virology 1998;244:504-12

48 Bonacini M, Govindarajan S, Blatt LM, et al. Patients coinfected with human immunodeficiency virus demonstrate higher levels of hepatic HCV RNA. J Viral Hepat 1999;6:203-8

49 Yokozaki S, Takamatsu J, Nakano I, et al. Immunologic dynamics in hemophiliac patients infected with hepatitis $C$ virus and human immunodeficiency virus: influence of antiretroviral therapy. Blood 2000;96:4293-9.

50 Daar ES, Lynn H, Donfield S, Gomperts E, et al. Hemophilia Growth and Development Study. Relation between HIV-1 and hepatitis $C$ viral load in patients with hemophilia. J Acquir Immune Defic Syndr 2001;26:466-72

51 Boncini $M$, Lin HJ, Hollinger B. Effect of coexisting HIV-1 infection on the diagnosis and evaluation of hepatitis $C$ virus. J Acquir Immune Defic Syndr 2001;26:340-4.

52 Causse X, Payen JL, Izopet J, et al. Does HIV influence the response of chronic hepatitis C to interferon treatment? J Hepatol 2000;32:1003-10.

53 Sanchez-Quijano A, Andreu J, Gavilan F, et al. Influence of human immunodeficiency virus type 1 infection on the natural course of chronic parenterally acquired hepatitis C. Eur J Clin Microbiol Infect Dis 1995; 14:949-53.

54 Berger A, Prondzinski MVD, Doerr HW, et al. Hepatitis $C$ viral load is associated with HCV genotype but not with HIV coinfection. J Med Virol 1996:48:339-43.

55 Rey D, Fritsch S, Schmitt C, et al. Quantitation of hepatitis C virus RNA in saliva and serum of patients coinfected with $\mathrm{HCV}$ and human immunodeficiency virus. J Med Virol 200 1:63:117-19.

56 Makris M. Preston FE, Rosendaal FR, et al. The natural history of chronic hepatitis $C$ in haemophiliacs. Br J Haematol 1996;94:746-52.

57 Pol S, Fontaine $H$, Carnot $F$, et al. Predictive factors for development of cirrhosis in parenterally acquired chronic hepatitis $\mathrm{C}$ : a comparison between immunocompetent and immunocompromised patients. J Hepatol 1998;29:12-19.

58 Lesens O, Deschenes $M$, Steben $M$, et al. Hepatitis $C$ virus is related to progressive liver disease in human immunodeficiency virus-positive haemophililiacs and should be treated as an opportunistic infection. J Infect Dis 1999;179:1254-8.

59 Benhamou $Y$, Bochet $M$, Di Martino, et al. Liver fibrosis progression in human immunodeficiency virus and hepatitis $C$ virus coinfected patients. Hepatology 1999;30:1054-8.

60 Telfer P, Sabin C, Devereux H, et al. The progression of HCV-associated liver disease in a cohort of haemophilic patients. Br J Haematol 1994;88:397-9.

61 Eyster ME, Diamondstone LS, Lien JM, et al. Natural history of hepatitis $C$ virus infection in multitransfused hemophiliacs: effect of coinfection with human immunodeficiency virus. The Multicenter Hemophilia Cohort Study. J Acquir Immune Defic Syndr 1993;6:602-10.

62 Soto B, Sanchez-Quijano A, Rodrigo L, et al. Human immunodeficiency virus infection modifies the natural history of chronic parenterally-acquired hepatitis $C$ with an unusually rapid progression to cirrhosis. J Hepatol 1997;26:1-5. 
63 Bierhoff E, Fischer HP, Willsch E, et al. Liver histopathology in patients with concurrent chronic hepatitis $\mathrm{C}$ and HIV infection. Virchows Arch 1997;430:271-7.

64 Puoti M, Bonacini M, Spinetti A, et al. Liver fibrosis progression is related to CD4 cell depletion in patients coinfected with hepatitis $C$ virus and human immunodeficiency virus. J Infect Dis 2001:183:134-7.

65 Garcia-Samaniego J, Soriano V, Castilla J, et al. Influence of hepatitis $C$ virus genotypes and HIV infection on histological severity of chronic hepatitis C. Am J Gastroenterol 1997;92:1 130-4

66 Rockstroh JK, Spengler U, Sudhop T, et al. Immunosuppression may lead to progression of hepatitis $C$ virus associated liver disease in hemophiliacs coinfected with HIV. Am J Gastroenterol 1996;91:2563-8.

67 Graham CS, Baden LR, Yu E, et al. Influence of human immunodeficiency virus infection on the course of hepatitis $c$ virus infection: a meta-analysis. Clin Infect Dis $2001 ; 33: 562-9$.

68 Di Bisceglie A. Hepatitis C. Lancet 1998;351:351-5.

69 International Interferon-Hepatocellular Carcinoma Study Group. Effect of interferon on progression of cirrhosis to hepatocellular carcinoma: a retrospective cohort study. Lancet 1998; 351:1535-9.

70 El-Serag H, Mason A. Rising incidence of hepatocellular carcinoma in the United States. N Engl J Med 1999;340:745-50.

71 Moriya K, Fujie $\mathrm{H}$, Shintani $\mathrm{Y}$, et al. The core protein of hepatitis $\mathrm{C}$ virus induces hepatocellular carcinoma in transgenic mice. Nat Med 1998;4:1065-7.

72 Ray RB, Steele R, Meyer K, et al. Transcriptional repression of p53 promoter by hepatitis $C$ virus core protein. J Biol Chem 1997:272:10983-6.

73 Ray RB, Steele R, Meyer K, et al. Hepatitis $C$ virus core protein represses p21WAF1/Cipl/Sidl promoter activity. Gene 1998;208:331-6.

74 García-Samaniego J, Rodríguez M., Berenguer J, et al. Hepatocellular carcinoma in HIV-infected patients with chronic hepatitis C. Am J Gastroenterol 2001;96:179-83.

75 Daar ES, Lynn H, Donfield S, et al. Hepatitis $\mathrm{C}$ virus load is associated with human immunodeficiency virus type 1 disease progression in hemophiliacs. J Infect Dis 2001;183:589-95.

76 Piroth L, Duong M, Quantin C, et al. Does hepatitis C virus coinfection accelerate clinical and immunological evolution of HIV-infected patients? AIDS 1998:12:381-8.

77 Dorrucci M, Pezzotti P, Phillips AN, et al. Coinfection of hepatitis $C$ virus with human immunodeficiency virus and progression to AIDS. Italian Seroconversion Study. J Infect Dis 1995; 172:1503-8.

78 Lasarte JJ, Garcia-Granero M, Lopez A, et al. Cellular immunity to hepatitis $C$ virus core protein and the response to interferon in patients with chronic hepatitis C. Hepatology 1998;28:815-22.

79 Diepolder HM, Zachoval R, Hoffmann RM, et al. Possible mechanism involving T response to non-structural protein 3 in viral clearance in acute hepatitis C virus infection. Lancet 1995;346:1006-7.

80 Rehermann B, Chisari FV. Cell mediated immune response to the hepatitis C virus. Curr Top Microbiol Immunol 2000;242:299-325.

81 Takaki A, Wiese M, Maertens G, et al. Cellular immune responses persist and humoral responses decrease two decades recovery from a single-source outbreak of hepatitis C. Nat Med 2000;6:578-82.

82 Mcmichael AJ, Rowland-Jones S. Cellular immune response to HIV. Nature 2001:410:980-7.

83 Graham CS, Koziel M. Why should hepatitis $C$ affect immune reconstitution in HIV-1-infected patients? Lancet 2000;356: 1865-6.

84 Lai MM. Hepatitis viruses and signal transduction: true to the core? Hepatology 2000;32:427-9.

85 Taya N, Torimoto $Y$, Shindo $M$, et al. Fas-mediated apoptosis of peripheral blood mononuclear cells in patients with hepatitis $\mathrm{C} . \mathrm{Br} J$ Haematol 2000;1 10:89-97.

86 Gavazzi P, Richallet $G$, Morand P, et al. Effects of double and triple antiretroviral agents on the HCV viral load in patients coinfected with HIV and HCV. Pathol Biol 1998:46:412-5.

87 Zylberberg H, Chaix ML, Rabian C, et al. Tritherapy for human immunodeficiency virus infection does not modify replication of hepatitis $C$ virus in coinfected subjects. J Infect Dis 1998;26:1 104-6.

88 Rockstroh JK, Theisen A, Kaiser R, et al. Antiretroviral triple therapy decreases HIV viral load but does not alter hepatitis $C$ virus $(\mathrm{HCV})$ serum levels in HIV-HCV-coinfected hemophiliacs. AIDS 1998;12:829-30.

89 Garcia-Samaniego J, Bravo R, Castilla J, et al. Lack of benefit of protease inhibitors on HCV viremia in HIV-infected patients. J Hepatol 1998;28:526-7

90 Gavazzi G, Bouchard O, Leclercq P, et al. Change in transaminases in hepatitis $C$ virus- and HIV-coinfected patients after highly active antiretroviral therapy: differences between complete and partial virologic responders? AIDS Res Hum Retroviruses 2000;20;16:1021-3.

91 Rutschmann OT, Negro F, Hirschel B, et al. Impact of treatment with human immunodeficiency virus (HIV) protease inhibitors on hepatitis $C$ viremia in patients coinfected with HIV J Infect Dis 1998:177.783-5.

92 Vento S, Garofano T, Renzini C, et al. Enhancement of hepatitis $C$ virus replication and liver damage in HIV-coinfected patients on antiretroviral combination. AIDS 1998;12:116-17.

93 Ragni MV, Bontempo FA. Increase in hepatitis $C$ virus load in hemophiliacs during treatment with highly active antiretroviral therapy. $J$ Infect Dis 1999:180:2027-9.

94 Sulkowski M, Thomas DL, Chaisson RE, et al. Hepatotoxicity associated with antiretroviral therapy in adults infected with human immunodeficiency virus and the role of hepatitis $C$ or $B$ virus infection. JAMA 2000;283:74-80.

95 Karras A, Rabian C, Zylberberg $\mathrm{H}$, et al. Severe anoxic hepatic necrosis in an HIV-1 hepatitis $C$ virus coinfected patient starting antiretroviral triple combination therapy. AIDS 1998;12:827-9.
96 Rodriguez-Rosado R, Garcia-Samaniego J, Soriano V. Hepatotoxicity after introduction of highly active antiretroviral therapy. AIDS $1998 ; 12: 1256$

97 Arribas JR, Ibanez C, Ruiz-Antoran B, et al. Acute hepatitis in HIV-infected patients during ritonavir treatment. AIDS 1998;12:1722-4.

98 Rodriguez-Resado R, Garcia-Samaniego J, Soriano V, et al. Hepatotoxicity after introduction of highly active antiretroviral therapy (HAART). Presented at the 12th World AIDS Conference, Geneva, 1998: abstract 12288

99 Brinkman K, ter Hofstede HJM, Burger DM, et al. Adverse effects of reverse transcriptase inhibitors: mitochondrial toxicity as common pathway. AIDS 1998:12:1735-44.

100 Duong M, Petit JM, Piroth $L$, et al. Association between insulin resistance and hepatitis $C$ virus chronic infection in HIV-hepatitis $C$ virus-coinfected patients undergoing antiretroviral therapy. J Acquir Immune Defic Syndr 2001:27:245-50.

101 Heathcote EJ, Shiffman ML, Cooksley WG, et al. Peginterferon alfa-2a in patients with chronic hepatitis $C$ and cirrhosis. N Engl J Med 2000;343: 1673-80.

102 Zeuzem S, Feinman SV, Rasenack J, et al. Peginterferon alfa-2a in patients with chronic hepatitis C. N Engl J Med 2000;343:1666-72.

103 Poynard T, Marcellin P, Lee SS, et al. Randomised trial of interferon alpha-2b plus ribavirin for 48 weeks or for 24 weeks versus interferon alpha-2b plus placebo for 48 weeks for treatment of chronic infection with hepatitis C virus. Lancet 1998;352: 1426-32.

104 McHutchison JG, Gordon SC, Schiff ER, et al. Interferon alpha-2b alone or in combination with ribavirin as initial treatment for chronic hepatitis C. N Engl J Med 1998;339:1485-92.

105 Boyer N, Marcellin P, Degott C, et al. Recombinant interferon- for chronic hepatitis $C$ in patients positive for antibody to human immunodeficiency virus. J Infect Dis 1992;165:723-6.

106 Mariott E, Navas S, del Romero J, et al. Treatment with recombinant-interferon of chronic hepatitis $\mathrm{C}$ in anti-HIV positive patients. J Med Virol 1993;40:107-11

107 Mauss S, Klinker H, Ulmer A, et al. Response to treatment of chronic hepatitis $C$ with interferon alpha in patients infected with HIV-1 is associated with higher CD4+ cell count. Infection 1998;26:16-19.

108 Del Pozo MA Arias JR, Pinilla J, et al. Interferon alpha treatment of chronic hepatitis $\mathrm{C}$ in HIV-infected patients receiving zidovudine: efficacy, tolerance, and response related factors. Hepatogastroenterology 1998;45:1695-701.

109 Soriano V, Rodriguez-Rosado R, Garcia-Samaniego J. Management of chronic hepatitis C in HIV-infected patients. AIDS 1999;13:539-46.

110 Soriano V, Bravo R, Garcia-Samaniego J, et al. A pilot study on the efficacy of escalating dosage of alpha-interferon for chronic hepatitis $C$ in HIV-infected patients. J Infect 1997;35:225-30.

111 Mauss S, Heintges T, Adams O, et al. Treatment of chronic hepatitis C with interferon-alpha in patients infected with the human immunodeficiency virus. Hepatogastroenterology 1995:42:528-34.

112 Vento S, Di Perri G, Cruciani M, et al. Rapid decline of CD+ cells after IFN- treatment in HIV-1 infection. Lancet 1993;341:958-9.

113 Pesce A, Taillan B, Rosenthal E, et al. Opportunistic infections and CD4 lymphocytopenia with interferon treatment in HIV-1-infected patients. Lancet 1993:341:1597.

114 Zylberberg $\mathbf{H}$, Benhamou Y, Lagneaux JL, et al. Safety and efficacy of interferon-ribavirin combination therapy in HCV-HIV coinfected subjects: an early report. Gut 2000;47:694-7

115 Landau A, Batisse D, Duong Van Huyen JP, et al. Efficacy and safety of combination therapy with interferon- $2 \mathrm{~b}$ and ribavirin for chronic hepatitis $C$ in HIV-infected patients. AIDS 2000;14:839-44.

116 Nasti G, Gennaro GD, Rizzardini G, et al. Chronic hepatitis C in HIV-coinfected patients: feasibility and efficacy of interferon-alpha2b and ribavirin combination therapy. J Acquir Immune Defic Synd 2001;26:299-300

117 Lafeuillade A, Hittinger G, Chadapaud S. Increased mitochondrial toxicity with ribavirin in HIV/HCV coinfection. Lancet 2001;357:280.

118 Kakuda TN, Brinkman K. Mitochondrial toxic effects and ribavirin. Lancet 2001:357:1803-4.

119 Hoggard PG, Kewn S, Barry MG, et al. Effects of drugs on 29,39-dideoxy-29,39-didehydrothymidine phosphorylation in vitro. Antimicrob Agents Chemother 1997;41:1231-6.

120 Soriano V, Garcia-Samaniego J, Perz-Olmeda M, et al. Pegylated interferon plus ribavirin for the treatment of chronic hepatitis $C$ in HIV-infected patients. 1st IAS Conference on HIV Pathogenesis and Treatment, Buenos Aires, Argentina, July 8-11, 2001:abstract 42.

121 Schlaak JF, Zum B, Gerken G, et al. Sustained HCV eradication after interleukin-2 therapy in patients with HIV/HCV coinfection. Association for the Study of Liver Disease Dallas, Texas, 1999:abstract 431A

122 Boyd AE, Tayler C, Norris S, et al. Liver transplantation and HIV-a case series of 7 patients. 8th Conference on Retroviruses and Opportunistic Infections, Chicago, 2001:abstract 578.

123 Vento S, Garofano T, Renzini C, et al. Fulminant hepatitis associated with hepatitis $A$ virus superinfection in patients with chronic hepatitis $C$ N Engl J Med 1998;338:286-90.

124 Mele A, Tosti ME, Stroffolini T. Hepatitis associated with hepatitis A superinfection in patients with chronic hepatitis C. N Engl J Med 1998:338: 1771.

125 Neilsen GA, Bodsworth NJ, Watts N. Response to hepatitis A vaccination in human immunodeficiency virus-infected and-uninfected homosexual men. J Infect Dis 1997;176:1064-7.

126 Roudot-Thoroval F, Bastie A, Pawlotsky JM, et al. Epidemiological factors affecting the severity of hepatitis $C$ virus-related liver disease: French survey of 6664 patients. Hepatology1997;26:485-90. 